Article

\title{
Equipment Maintenance Business Model Innovation for Sustainable Competitive Advantage in the Digitalization Context: Connotation, Types, and Measuring
}

\author{
Juhong Chen, Ruijun Zhang * and Di Wu $\mathbb{D}$ \\ School of Economics and Management, Xi'an University of Technology, Xi'an 710048, China; \\ chen-juhong@163.com (J.C.); wdfrancis@163.com (D.W.) \\ * Correspondence: zhangruijun01@126.com; Tel.: +86-29-6266-0206
}

Received: 10 October 2018; Accepted: 28 October 2018; Published: 31 October 2018

check for updates

\begin{abstract}
The equipment maintenance services have become a new profit center and an important way to gain sustainable competitive advantage for manufacturing enterprises. The business model is an important tool for manufacturing enterprises to derive economic benefits from sustainable competitive advantage in the context of digitalization technologies, such as IoT, big data, and cloud computing. At present, the concept of equipment maintenance business model innovation is still vague, and it is rare to report on the innovation behaviors and types of equipment maintenance business models adopted by manufacturing enterprises. Based on literature analysis of equipment maintenance services and business model innovation, following business model gestalt theory, the concept of equipment maintenance business model innovation is analyzed at the business-level, the types are divided into novel and efficient following value sources- "innovation and efficiency". The initial scale is developed through literature investigation, semi-structured interviews and expert reviews, and tested by exploratory and confirmatory factor analysis by using the data of two independent large-sample questionnaires. The results indicate that the behavior and types of equipment maintenance business model innovation can be described by two types and 19 items.
\end{abstract}

Keywords: equipment maintenance; business model innovation; equipment maintenance business model innovation connotation; measuring; digitalization; sustainable competitive advantage

\section{Introduction}

With the rise of the services economy, providing professional maintenance services to customer enterprises has become an important way for manufacturing enterprises to gain sustainable competitive advantage. The integration of equipment maintenance services not only meets the needs of customers outsourcing non-core activities, but also helps manufacturers to break away from productization traps and gain sustainable profit growth points [1]. Especially in recent years, the development and application of digitalization technologies represented by IoT, big data, cloud computing, etc., has brought abundant opportunities for manufacturing enterprises to efficiently provide equipment maintenance services [2], and has promoted industrial markets to adopt predictive maintenance with the $25-30 \%$ of efficiency improvement [3]. Predictive maintenance refers to the process that equipment manufacturing enterprises collect data of the operating condition of equipment, analyze and diagnose the health management data of equipment, predict the time when equipment failures may occur, then make appropriate decisions about equipment maintenance services through the application of digitalization technologies [4]. In this context, the efficiency of equipment maintenance will be greatly improved [5]. However, Roland Berger found that although $81 \%$ of respondents had 
realized that predictive maintenance would help to improve customer performance and had invested in digitalization technologies, more than $50 \%$ of respondents were facing the profit problem due to the lack of a predictive maintenance business model [6].

Business model is a bridge between technology input and economic output [7], and its innovation is a key source of sustainable competitive advantage [8]. Only if the business model is designed and changed to support the provision of predictive maintenance services can manufacturing enterprises achieve the expected economic benefits and sustainable competitive advantage from the provision of digitalization equipment maintenance services. Numerous studies have shown that business model innovation is a vital leverage to improve the sustainability performance of enterprises [9], and can improve the resilience of an enterprise to the rapidly-changing business environment and constitute a sustainable competitive advantage of the enterprise [10]. More specifically, the business model innovation aimed at aligning incentives with revenue is conducive to making better use of product/service offerings to achieve sustainable competitive advantage [11], and the product-service system business model innovation will improve the marginal environment at best [12]. However, almost all of the above studies on business model innovation were on firm- level. It is difficult to provide theoretical guidance for manufacturing enterprises on how to capture economic benefit and gain sustainable competitive advantage through equipment maintenance services provision. At the same time, although some scholars have already investigated digitalization technologies and technical capabilities supporting maintenance services [13,14], and the commercial value of them [15], there are few studies that have explored maintenance business model in combination with the commercial value of equipment maintenance services and digitalization technologies. In addition, although there are some studies have initially explored the capabilities and governance issues required to design and innovate equipment maintenance business model in the mining and construction industry [16], but mainly from the perspective of management practices. how manufacturing enterprises design or innovate equipment maintenance business model in the digitalization context is still not resolved. There is a lack of the connotations and types of identification of equipment maintenance business model innovation. Furthermore, there is a lack of the construction of measurement system for equipment maintenance business model innovation.

The aim of this paper is to compensate for the above gaps, and the focus of this paper is the following two issues: (1) What are the connotations and types of equipment maintenance business model innovation on business-level? (2) How to measure the behavior and types of equipment maintenance business model innovation?

In order to solve the aforementioned two problems, we firstly analyzed the connotations and types of equipment maintenance business model innovation on business-level, based on review and analysis of existing research on the connotation and types of business model innovation, combining the functions of equipment maintenance services in the digitalization context with business model gestalt theory. Secondly, we developed the initial scale through literature investigation, semi-structured interviews, expert reviews and small-scale questionnaire pre-test, then collected questionnaire data using the large sample questionnaire through a combination of random and theoretical sampling methods. Finally, we corrected and validated the measurement scale through exploratory factor analysis and confirmatory factor analysis. The findings of this paper are likely to lay a theoretical foundation for the follow-up relationship research during equipment maintenance business model, strategy and performance in the digitalization context. At the same time, it may also provide the guidance for maintenance business model innovation practice of service-oriented manufacturing enterprises under the two-wheel drive of digitalization technologies innovation and the needs of customers' outsourcing equipment maintenance.

Therefore, the contribution of this paper is to define the connotations and classify the types of equipment maintenance business model innovation in the digitalization context and to quantify the research on behaviors and types of equipment maintenance business model innovation. This breaks through the existing research limitations about business model innovation only on the firm-level 
and provides a measurement tool for quantitative research on equipment maintenance business model innovation.

This paper consists of six sections. Section 2 summarizes the related researches of maintenance services. Section 3 analyzes the connotation and types of equipment maintenance business model innovation on business-level based on the result of existing research on the connotation and types of business model innovation on firm-level. Section 4 develops an initial items pool through a literature investigation, semi-structured interviews, and expert reviews. Section 5 validates this initial item pool and finalizes the scale by exploratory and confirmatory factor analysis using data from two independent large-sample questionnaires. Section 6 discusses the contributions to research and practice, limitations of the paper, and recommendations for future research.

\section{Equipment Maintenance Services}

\subsection{The Types of Equipment Maintenance Services}

With industrialization, manufacturing enterprises are gradually reducing manpower. However, because of relying on equipment too much, there are risks of economic losses and safety incidents caused by equipment failures [17]. Equipment maintenance has become the basis for the enterprises' normal operation, and received much attention in the industrial field. With the advance of industrialization, the functional structure and technical complexity of the equipment have been increasing, the cost of equipment maintenance has increased dramatically, and even accounted for $60-70 \%$ of the total operation cost in equipment-using enterprises (the customer enterprises of the equipment manufacturing enterprises, hereinafter referred to as the "customer enterprises") [18]. In order to improve operation efficiency and reduce operation cost, customer enterprises often choose to outsource equipment maintenance. It is an opportunity for equipment manufacturers with technological advantages to gain more revenue and sustainable competitive advantage. Corrective, preventive and predictive equipment maintenance services are provided to customer enterprises by equipment manufacturing enterprises in the field of industrial maintenance (see Table 1 for details).

(1) Corrective equipment maintenance services. The equipment failure is that an equipment has been turned off and needs to be handled manually to start again [19]. Sudden failures will cause the units on the associated production line to be directly or forced to close, the heavy economic losses and serious social impacts, even the malignant or catastrophic accidents. Corrective equipment maintenance services are triggered by equipment failure, a series of random reactive activities, such as overhaul and replacement. The equipment manufacturing enterprise passively responds to the equipment repairing needs of customer enterprise, and gains revenue from accessories and repair services. The key technologies involved in corrective equipment maintenance services are the advantage technologies of equipment manufacturers such as equipment manufacturing, repairing.

(2) Preventive equipment maintenance services. The increasing of the frequency of preventive maintenance can minimize downtime, correct historical errors [20], and reduce the inventory cost of work in process [21]. Preventive equipment maintenance services are triggered by scheduling in the operating manual, a series of periodic reactive activities. The equipment manufacturing enterprise executes actively, and gains revenue from overhaul and minor repair. The key technologies involved in preventive equipment maintenance services are computational technologies (such as genetic algorithms, Monte Carlo policy, Markov degradation systems, and Bayesian theory methods) and equipment overhaul/repair technologies (such as splitting, overhaul, and replacement of parts). Optimal fit maintenance arrangements are often determined by key technical calculations. However, the equipment maintenance scheduling determined in the planning stage is only applicable to the equipment with a defined life cycle, not applicable to the equipment with uncertain degradation models [22]. In addition, regular equipment maintenance activities often have great blindness. It is prone to repair fatigue. Even worse, an unnecessary of removal or replacement of the well-operated equipment will cause a waste of resources related to maintenance. 
(3) Predictive equipment maintenance services. Based on monitoring the operating condition of the equipment, it can be achieved to predict the life cycle of the equipment by using data analysis technology, extend the life of the equipment, and improve the reliability of the equipment [23]. Predictive equipment maintenance services are triggered by the operating condition of the equipment, a series of perceptive activities. The equipment manufacturing enterprise monitors actively the equipment in the customer enterprises, identifies and assesses customers' needs, and gains revenue from equipment safe running time and behavior recommendation services. The key technologies involved in predictive equipment maintenance services are data collection and analysis technologies, such as IoT, cloud computing, predictive analysis (such as fuzzy logic, neural networks, evolutionary algorithms, machine learning, probabilistic reasoning), and equipment repair technologies (such as splitting and replacing parts). Currently, there are two types of predictive equipment maintenance services adopted by the industry: condition-based equipment maintenance and prognostics-based equipment maintenance. Condition-based equipment maintenance refers to continuously monitor and collect data on the condition of critical tasks and key components, regularly analyze the collected data, and carry out maintenance activities as needed, such as inspection, replacement, overhaul, and repair and reset based on the current condition. It is a near real-time equipment maintenance service, and can avoid the equipment failure approximately optimally [24]. Prognostics-based equipment maintenance refers to continuously collect and analyze equipment operating data, predict the remaining life of the equipment based on the actual stress load. It is a real-time equipment maintenance service, and can avoid equipment failures [25]. In addition to repair or replacement of equipment based on operating condition data, predictive equipment maintenance services further develop a series of targeted interventions with analysis of various behavioral and environmental parameters [26]. These interventions include correcting the wrong operating habits of customers, optimizing the environment in customer operations and equipment operating, and predicting the customer's potential needs of maintenance services and so on [27]. It will improve the efficiency of equipment maintenance in the later stages, and result in the better availability and stability of the equipment. For example, GE instructed the airline to correct the position of the wing when landing, helping Alitalia save fuel of aircraft flight [13].

Table 1. Main types of equipment maintenance services.

\begin{tabular}{|c|c|c|c|}
\hline Features & Corrective & Preventive & Predictive \\
\hline Types & as failure & as scheduling & as needs \\
\hline Trigger mechanism & reactive passively & reactive actively & perceptive actively \\
\hline Service Timing & random & periodic & real-time \\
\hline Downtime & longest & shorter & proximity minimization \\
\hline Maintenance node & Equipment condition & failure & maintenance \\
\hline Key techniques & fault repair technology & $\begin{array}{l}\text { key computational } \\
\text { technology; overhaul and } \\
\text { repair technology }\end{array}$ & $\begin{array}{c}\text { data collection and analysis technology; } \\
\text { repair technology }\end{array}$ \\
\hline Activities & $\begin{array}{l}\text { replacement, overhaul or } \\
\text { repair of equipment } \\
\text { after failure }\end{array}$ & $\begin{array}{l}\text { inspection, repair, or } \\
\text { replacement of equipment } \\
\text { on a regular basis; } \\
\text { forecast or update regular } \\
\text { plans based on design } \\
\text { and experience }\end{array}$ & $\begin{array}{c}\text { repair or replacement of equipment } \\
\text { on needs; } \\
\text { monitor and collect condition data; } \\
\text { seamless storage, large-scale computing; } \\
\text { diagnose, predict life cycle and } \\
\text { develop interventions }\end{array}$ \\
\hline
\end{tabular}

Source: Own elaboration. 


\subsection{The Functions of Digitalization Equipment Maintenance Services}

The capability boundaries of traditional equipment have been broadened through the development and application of digitalization technologies such as IoT, big data and cloud computing [13]. These provide technical support for predictive equipment maintenance. Compared with traditional corrective and preventive equipment maintenance, predictive equipment maintenance is an equipment maintenance service promoted by digitalization technologies. The functions of predictive equipment maintenance services are closely related to digitalization technologies. In the digitalization context, the operating condition and operating environment of the install-based equipment can be remotely monitored in real-time, the accurate equipment maintenance can be achieved by analyzing the real-time data. These provide the decision-making basis for equipment optimization and customers' needs forecasting [28]. IBM pointed out that predictive equipment maintenance services are the process of monitoring (data collection), diagnostic (data management, integration), prediction (data analysis, forecasting), and optimization (improving products and services) to the equipment by using digitalization technologies. Neusoft proposed that the functions of digitalization equipment maintenance services include descriptive analysis (stating what happened in the past), diagnostic analysis (finding why it happen in the past), predictive analysis (predicting what will happen in the future), and descriptive analysis (determining what to do in the future), etc.

In summary, this paper points out that the equipment maintenance provided by manufacturing enterprises in the digitalization context has four main functions of monitoring, diagnosis, prediction and optimization (see Table 2 for details). Monitoring is to collect real-time data on equipment usage and operating (condition or environment) by using sensors. Diagnostics and prediction are to calculate and analyze real-time data from the running equipment and extract knowledge. Diagnostics is a judgment of the current condition of the equipment. Prediction is to mine data and reason about future equipment health trends and potential customers' needs. Optimization is to innovate or improve equipment functions and equipment maintenance services based on diagnostic and predictive results.

Table 2. The functions description of digitalization equipment maintenance services.

\begin{tabular}{cl}
\hline Content & \multicolumn{1}{c}{ Functions Description } \\
\hline Monitoring & $\begin{array}{l}\text { Monitor and collect real-time data of equipment operating condition, operating environment, } \\
\text { equipment operating and usage and customer operating scenario activities; Use wireless } \\
\text { technologies to pass these data back to data analysis center. }\end{array}$ \\
\hline \multirow{2}{*}{ Diagnosis } & $\begin{array}{l}\text { Perform signal preprocessing and feature extraction based on the recovered data; Diagnose } \\
\text { equipment failure domains and customer behavior habits and preferences, etc.; Output the } \\
\text { error correction or amendment decisions. }\end{array}$ \\
\hline \multirow{3}{*}{ Prediction } & $\begin{array}{l}\text { Perform signal preprocessing and feature extraction based on the recovered data; Output the } \\
\text { warning domains, security domains during the equipment life cycle and the potential } \\
\text { customer demands through predictive and prognostic analysis; Provide guidance for the } \\
\text { sustainable provision of maintenance services in the later period. }\end{array}$ \\
\hline & $\begin{array}{l}\text { Improve equipment performance and overall operating performance and optimize } \\
\text { customers' operating processes through combining rich diagnostic and } \\
\text { predictive information. }\end{array}$ \\
\hline
\end{tabular}

\section{The Concept of Equipment Maintenance Business Model Innovation in the Digitalization Context}

\subsection{The Connotation of Equipment Maintenance Business Model Innovation in the Digitalization Context}

Equipment maintenance business model innovation is the transformation and reconstruction of the architecture of the value creation and capture on the equipment maintenance services business-level $[29,30]$, belonging to the category of business model innovation. It is a refinement of the connotation of business model innovation with the development of equipment maintenance 
services business and the establishment of business model innovation status in academia. Based on combining the functions of equipment maintenance services and the connotation of business model innovation, this paper defines the connotation of equipment maintenance business model innovation of manufacturing enterprises.

\subsubsection{The Connotation of Business Model Innovation}

The Internet has created an era of "business model wins". The new business model has created many business opportunities and brought up some great companies. This phenomenon has been widely recognized by the academia. "Value Creation in E-business" published in the SMJ by Zott and Amit in 2001 formally established a milestone of "business model" in the academic research. They proposed that business model is a construct that describes transaction content, transaction structure and transaction governance, aiming to create and capture value by developing business opportunities [31]. Subsequently, theoretical research on business model quickly becomes a hot topic. As the potential value logic of an enterprise, business model describes the basic principles of value creation, value delivery, and value capture [32], solves how enterprises achieve value proposition and profitability issues [33].

As the rapid changes of the business environment, scholars have been aware of the high dependence of business model on the external environment. Only by continuously re-examining and innovating business model can enterprises remain viable, competitive, sustainable and difficult to imitate [34-36]. The essence of business model innovation is a process of reconstructing the enterprise value system cross-enterprise boundary, representing an underutilized source of value, is an effective way for enterprises to gain new sustainable competitive advantages [37-39]. Based on value creation theory, the connotation of business model innovation is gradually defined. Chesbrough and Rosenbloom advocated that business model innovation discovered a new mapping relationship between technology potential and economic value, and improved the conversion of technology value into success [7]. Teece claimed that business model innovation was a system-level innovation about the basic structure of value creation and value capture, was an important weapon to change the competition pattern of market for enterprises [33]. Nyangon and Byrne considered business model innovation referred to the development of new organizational forms to create, deliver and capture value for realizing an enterprise future, and further proposed that a shared or polycentric business model innovation could animate high levels of service reliability and resiliency to meet customer's diversifying needs and optimize processes in customer enterprises, thereby improve the enterprise operation and customer satisfaction [40]. Sosna and Trevinyo-Rodríguez viewed business model innovation as a strategic trial-and-error mechanism for a transforming enterprise driven by the external environment [41]. Foss and Saebi defined business model innovation as the designed, novel or non-trivial changes of the key elements of an enterprise's business model and/or the architecture linking these elements [42]. Wang and Dong proposed that business model innovation was the innovation and transformation of a series of activities and structures for value creation, delivery and capture based on the coordination and cooperation of resources and capabilities, was a systematic innovation activity [43]. Luo, Xiang, and Ning proposed that business model innovation was the logical change of enterprise's value creation and value capture through the construction of new transaction structure and new institution [44].

Most of the works on the connotation of business model innovation is at the firm-level. It is difficult to provide theoretical guidance for manufacturing enterprises to innovate or design business model on equipment maintenance services at the business-level. In fact, as customer enterprises increasingly focusing on equipment lifecycle costs, equipment manufacturers have begun to pay attention to market opportunities brought by equipment maintenance services and considered equipment maintenance services as a new profit center and an important way to gain a sustainable competitive advantage. Therefore, it is vital to innovate or design business model on business-level for manufacturing enterprises to be the equipment maintenance services providers [29]. Unfortunately, although some 
studies have discussed the importance of maintenance business model from the perspectives of technology [45] and value [30], its connotation has not been clearly defined. Therefore, discussion in-depth on the connotation of equipment maintenance business model innovation is an urgent academic problem to be solved.

\subsubsection{The Connotation of Digitalization Equipment Maintenance Business Model Innovation}

The connotation of equipment maintenance business model innovation in the digitalization context can be analyzed from two aspects.

On the one hand, equipment maintenance business model innovation is a concept subdivided from business model innovation. Although it belongs to the category of business model innovation, there are also differences in value logic. For manufacturing enterprises, business model innovation is a systemic firm-level innovation. It comprehensively considers customers' needs, various resources owned by enterprises and stakeholder relationships [46], emphasizes on the implementation of firm strategy, innovation and change of the firm's overall value creation and value capture logic, consistent with firm's goals. Equipment maintenance business model innovation is a systemic business-level innovation. It considers the customer enterprise's explicit or implicit needs for the specific equipment maintenance, resources, and capabilities related to equipment maintenance services and stakeholder relationships associated with equipment maintenance services, emphasizes on the implementation of servitization strategy (business-level strategy), innovation and change of the value creation and capture logic of equipment maintenance services, consistent with equipment maintenance services business goals.

On the other hand, equipment maintenance business model innovation in the digitalization context is closely related to the functions of monitoring, diagnosis, prediction and optimization of equipment maintenance services under digitalization technologies. Based on this, the essence of equipment maintenance business model innovation in digitalization context is optimization and upgrading of traditional equipment maintenance services based on digitalization technologies, such as IoT, big data, and cloud computing, redesigning the way of value creation, delivery and profit distribution, aiming to improve customer enterprises operation performance, will reduce operation costs and sustainably innovate to value for their customer enterprises.

It is not difficult to find that the concept of equipment maintenance business model innovation in the digitalization context is derived from business model innovation and combines the functions of digitalization equipment maintenance services. Therefore, as the potential value logic of the equipment maintenance services provided by manufacturing enterprises, equipment maintenance business model describes the equipment maintenance services contents designed by manufacturing enterprises, the basic principle of value creation for the stakeholders, and the value logic of equipment maintenance services. Equipment maintenance business model innovation in the digitalization context is that manufacturing enterprises redesign and optimize equipment performance or maintenance services contents, change the process of equipment maintenance services value creation, propose the new methods of equipment maintenance services transaction and profit distribution with customer enterprises by using the functions of monitoring, diagnosis, prediction, and optimization of digitalization equipment maintenance services. It is a systemic innovation based on the comprehensive consideration of customer needs, equipment maintenance resources owned or integrated, and equipment maintenance stakeholder relationships.

\subsection{The Types of Equipment Maintenance Business Model Innovation in the Digitalization Context}

Only a scientific classification of business model innovation can better identify the characteristics of different business model innovation, thereby lay the foundation for the research of business model design or innovation [47]. This paper summarized the mainstream classification criteria for business model innovation, then divided the types of equipment maintenance business model innovation in the digitalization context based on the common classification criterion, described the connotation of two 
types by combining with the functions of equipment maintenance services provided by manufacturing enterprises in the digitalization context and business model gestalt theory.

Scholars insisted of the different classification criteria for business model innovation, the classification results had not yet reached an agreement. At present, the mainstream classification criteria for business model innovation include sources of value, innovation degree, market perception, innovation scope, and sources of competitive advantage, etc. (see Table 3 for details).

Table 3. The types of business model innovation.

\begin{tabular}{|c|c|c|c|}
\hline Classification Criteria & \multicolumn{2}{|c|}{ Classification Results } & Representative Literature \\
\hline Sources of value & \multicolumn{2}{|c|}{$\begin{array}{l}\text { (1) Novel business model innovation: connect the unconnected stakeholders, } \\
\text { connect with transaction participants in new ways, or design new transaction } \\
\text { mechanisms. The essence is to adopt a new way of economic exchange. } \\
\text { (2) Efficient business model innovation: simplify transactions, reduce transaction } \\
\text { complexity, or reduce information asymmetry, aggregate demands, speed up } \\
\text { transactions, reduce inventory, provide transaction scalability, or reduce } \\
\text { direct and indirect costs of transactions. The essence is to reduce transaction } \\
\text { costs and improve transaction efficiency. }\end{array}$} & $\begin{array}{l}\text { Zott and Amit (2007); } \\
\text { Dang (2015); } \\
\text { Hu (2015); } \\
\text { Wu (2016); } \\
\text { Li (2016, 2017, 2018); } \\
\text { Gerdoçi (2017); } \\
\text { Sun (2018) }\end{array}$ \\
\hline Innovation degree & \multicolumn{2}{|c|}{ 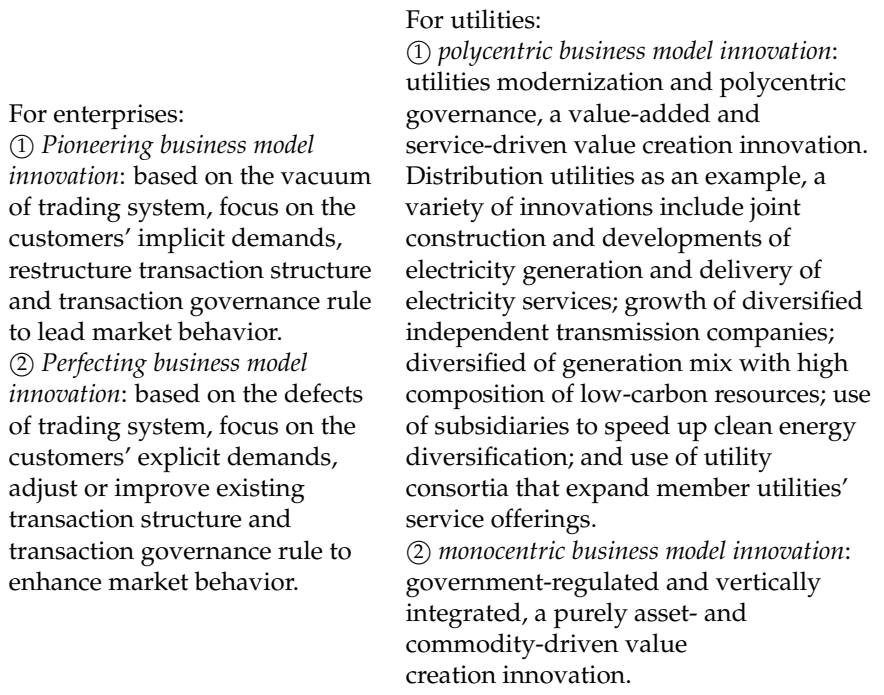 } & $\begin{array}{l}\text { Luo, Liu, Xiang and } \\
\text { Ning (2018); } \\
\text { Nyangon and Byrne (2018) }\end{array}$ \\
\hline Market perception & \multicolumn{2}{|c|}{$\begin{array}{l}\text { (1) Market-driven business model innovation: identify market explicit demands, } \\
\text { improve the existing market structure and trading system, adjust market } \\
\text { behavior. It is a quick response to the market. } \\
\text { (2) Driving-market business model innovation: mining market implicit demands, } \\
\text { construct a new market structure and trading system, innovate market } \\
\text { behavior. It is a forward-looking foresight of the market. }\end{array}$} & Cui and Jiang (2013) \\
\hline Innovation scope & \multicolumn{2}{|c|}{$\begin{array}{l}\text { (1) Closed business model innovation: focus on a single enterprise and financial } \\
\text { resources; the focus enterprise chooses operational activities, resource } \\
\text { systems and management systems to improve and maintain own returns. } \\
\text { Innovation cognition has not broken through firm boundary. } \\
\text { (2) Open business model innovation: focus on multiple entities such as } \\
\text { enterprises, customers, suppliers, and other resources such as finance, } \\
\text { production, and knowledge; the focus enterprise creates and transfers new } \\
\text { knowledge to stakeholders to improve related activities to implement } \\
\text { strategies and guide activities between multiple actors. Innovation cognition } \\
\text { has broken through firm boundary. }\end{array}$} & $\begin{array}{l}\text { Chesbrough (2007); } \\
\text { Saebi and Foss (2015); } \\
\text { Qi and Chen (2016); } \\
\text { Jiang and Cai (2016) }\end{array}$ \\
\hline $\begin{array}{l}\text { Sources of } \\
\text { competitive } \\
\text { advantage }\end{array}$ & \multicolumn{2}{|c|}{$\begin{array}{l}\text { (1) Business model innovation based on production technology: focus on promoting } \\
\text { new production technologies to improve the technical parameters in the } \\
\text { production function and promote the exertion of labor and capital efficiency. } \\
\text { (2) Business model innovation based on operating methods: focus on promoting } \\
\text { new operating methods to improve the operating parameters in the } \\
\text { production function. }\end{array}$} & $\begin{array}{l}\text { Cheng, Sun, Song and } \\
\text { Zen (2012) }\end{array}$ \\
\hline
\end{tabular}

Source: Own elaboration.

Through review and combing, the source of value is the common classification criterion for business model innovation. This is because novel and efficient types are not only the response to Schumpeter's (1934) two sources of value creation- "innovation and efficiency"- but also the basic 
choice for enterprises to create value in an uncertain environment (Miller, 1996). Following this classification criterion, this paper divides equipment maintenance business model innovation in the digitalization context into two types of efficient equipment maintenance business model innovation and novel equipment maintenance business model innovation (see Table 4 for comparative analysis).

Table 4. Comparison between two types of equipment maintenance business model innovation.

\begin{tabular}{ccll}
\hline & Monitoring & $\begin{array}{l}\text { Efficient Equipment Maintenance } \\
\text { Business Model Innovation }\end{array}$ & $\begin{array}{l}\text { Novel Equipment Maintenance } \\
\text { Business Model Innovation }\end{array}$ \\
\cline { 2 - 4 } $\begin{array}{c}\text { The functions of } \\
\text { digitalization } \\
\text { equipment } \\
\text { maintenance }\end{array}$ & Diagnosis & $\begin{array}{l}\text { the abnormal data of } \\
\text { equipment operating }\end{array}$ & $\begin{array}{l}\text { equipment operating environment } \\
\text { customers' behaviors, habits } \\
\text { and preferences }\end{array}$ \\
\cline { 2 - 4 } & Prediction & life cycle trends of equipment & $\begin{array}{l}\text { customer enterprises' } \\
\text { implicit demands }\end{array}$ \\
\cline { 2 - 4 } & Optimization & $\begin{array}{l}\text { equipment performance } \\
\text { and features }\end{array}$ & $\begin{array}{l}\text { customer enterprises' } \\
\text { operating processes }\end{array}$ \\
\cline { 2 - 4 } $\begin{array}{c}\text { value proposition } \\
\text { innovation }\end{array}$ & $\begin{array}{l}\text { avoid equipment failure } \\
\text { approximate optimally }\end{array}$ & $\begin{array}{l}\text { find new equipment services ideas } \\
\text { business model }\end{array}$ \\
\cline { 2 - 4 } & $\begin{array}{c}\text { consolidate and expand existing } \\
\text { innovation }\end{array}$ & $\begin{array}{l}\text { equipment maintenance market, } \\
\text { improve the transaction channels } \\
\text { within the industry }\end{array}$ & $\begin{array}{l}\text { open new markets across industry } \\
\text { boundaries, build a business } \\
\text { ecosystem of real-time interaction } \\
\text { and information sharing }\end{array}$ \\
\cline { 2 - 4 } & $\begin{array}{c}\text { value capture } \\
\text { innovation }\end{array}$ & $\begin{array}{l}\text { the real-time control of transaction } \\
\text { cost of equipment } \\
\text { maintenance services }\end{array}$ & $\begin{array}{l}\text { the new transaction mechanisms } \\
\text { or pricing models of equipment } \\
\text { maintenance services }\end{array}$ \\
\hline
\end{tabular}

Source: Own elaboration.

\subsubsection{Efficient Equipment Maintenance Business Model Innovation}

In the business model innovation theory, efficient business model innovation is to create value to reduce transaction costs and improve transaction efficiency [37]. Therefore, this paper proposes that efficient equipment maintenance business model innovation is that manufacturing enterprises provide equipment maintenance services for customer enterprises with high efficiency and low cost, and gain benefits and sustainable competitive advantage. It aims to simplify the transaction of existing equipment maintenance services, reduce information asymmetry in equipment maintenance services transaction, thereby aggregate the needs of equipment maintenance services, and accelerate equipment maintenance services transaction. The development of digitalization technologies provides an opportunity for manufacturing enterprises to efficiently provide equipment maintenance services. Manufacturing enterprises achieve real-time monitoring of equipment operating condition and obtain equipment operating data in the digitalization context. This greatly weakens the information asymmetry of the needs of equipment maintenance services during the equipment running, increases the accuracy of equipment maintenance services transactions. Diagnosing the abnormal data of equipment operating helps to predict equipment life cycle trends, further to optimize equipment performance and upgrade equipment features. This greatly simplifies the coordination mechanism in the process of equipment maintenance services, reduces the transaction cost of equipment maintenance.

Follow business model gestalt theory [48], equipment maintenance business model innovation can be decomposed into three aspects of equipment maintenance value proposition innovation, equipment maintenance value creation innovation, equipment maintenance value capture innovation. First, in terms of equipment maintenance value proposition innovation, the data-driven equipment maintenance decisions can avoid equipment failure approximate optimally, and improve the efficiency of equipment maintenance transaction. Second, in terms of equipment maintenance value creation innovation, manufacturing enterprises using digitalization technologies can consolidate and expand the existing equipment maintenance markets, improve the transaction channels within the industry, optimize existing processes, knowledge and technologies related to equipment 
maintenance services and data analysis. And finally, in terms of equipment maintenance value capture innovation, the real-time control of parts inventory cost, marketing cost, transaction processing cost, communication cost during equipment maintenance services transaction can reduce transaction costs for equipment maintenance services. In short, efficient equipment maintenance business model innovation is aimed at improving the transaction efficiency of equipment maintenance services and reducing the transaction cost of equipment maintenance services.

\subsubsection{Novel Equipment Maintenance Business Model Innovation}

In the business model innovation theory, novel business model innovation is to create value by providing differentiated products and services [37]. Therefore, this paper proposes that novel equipment maintenance business model innovation is that manufacturing enterprises provide innovative and distinctive types and combinations of equipment services to create value for customer enterprises, and gain benefits and sustainable competitive advantage. It aims to connect unconnected equipment maintenance stakeholders, or connect transaction participants of equipment maintenance services in new ways, or design a new transaction mechanism of equipment maintenance services. The development of digitalization technologies provides technical support for manufacturing enterprises to develop novel equipment maintenance services. Manufacturing enterprises achieve real-time monitoring of the equipment operating environment and obtain data on customers' behaviors, habits and preferences in the digitalization context. This lays the foundation for the manufacturing enterprise changing the relationship with customer enterprises from transactional to relational. User image analysis can prospectively predict customers' implicit needs, helps to open and seize new market opportunities, further optimize customer operation processes and build customer lock-ups to greater extent.

Follow business model gestalt theory, novel equipment maintenance business model innovation can also be decomposed into three aspects of equipment maintenance value proposition innovation, equipment maintenance value creation innovation, equipment maintenance value capture innovation. First, in terms of equipment maintenance value proposition innovation, through continuous analysis of customer preference data, manufacturing enterprises can find new equipment services ideas to meet customers' implicit needs. This data-driven innovation in equipment maintenance services can rebuild customers' habits of consumption and usage, bring the unique value experience to customers and increase enterprises' profits. Second, in terms of equipment maintenance value creation innovation, manufacturing enterprises using digitalization technologies often open up new markets across industry boundaries, find new partners to seize new market opportunities, build a business ecosystem of real-time interaction and information sharing for partners to fully integrate and deepen the use of new resources, and continuously explore new processes, knowledge and technologies related to equipment maintenance services and data analysis. And finally, in terms of equipment maintenance value capture innovation, manufacturing enterprises using digitalization technologies are likely to build the new transaction mechanisms of equipment maintenance services, creatively develop the new pricing models for equipment maintenance services, and share the benefits and risks of equipment maintenance services with partners and customers. In short, novel equipment maintenance business model innovation is aiming at continuously exploring the innovative economic exchange model of equipment maintenance services.

\section{The Scale Development of Equipment Maintenance Business Model Innovation}

Follow the scale development programs of Churchill [49], Luo and Xiang [50], and Zhang [51], this paper develops a measurement scale for equipment maintenance business model innovation in accordance with the following two steps. Step 1, the initial measurement scale is generated by combining literature investigation and semi-structured interviews, subsequently submitted to the experts in the field of research for the discretion of language expression to ensure that the initial measurement scale can be clearly expressed. Step 2, the validity tests including exploratory and confirmatory factor analysis of the measurement scale are executed to purify verify the scale. 


\subsection{Literature Investigation}

By filtering and referencing the existing measurement scales, and combining the deduction of the connotation of equipment maintenance business model innovation, the alternative items of two types in the measurement items pool are drawn up (see Table 5).

Table 5. The initial measurement scale of equipment maintenance business model innovation.

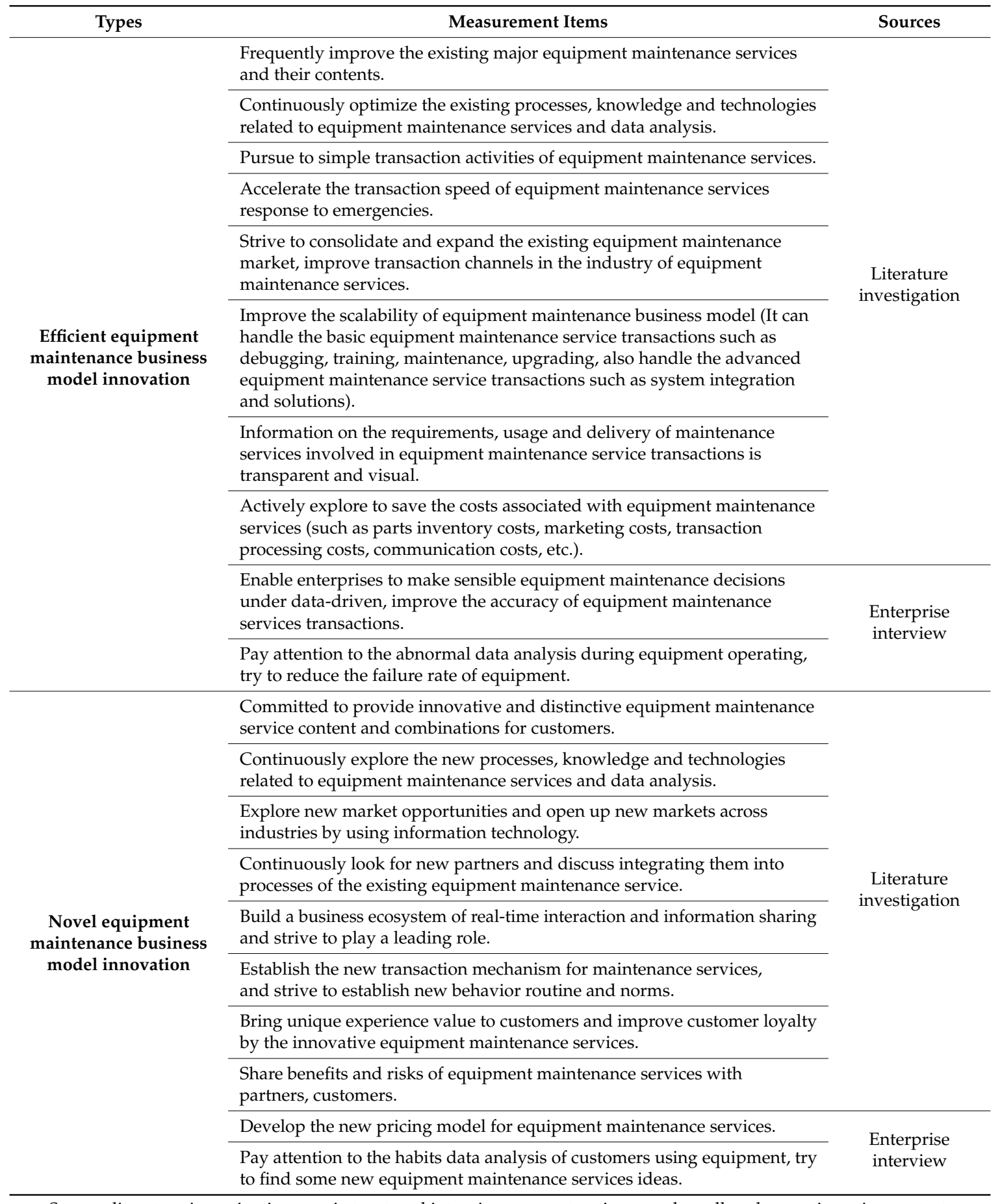

Source: literature investigation, semi-structured interviews, expert reviews, and small-scale questionnaire pre-test.

The measurement items of efficient equipment maintenance business model innovation mainly refer to Zott and Amit's efficient business model [37], He and Wong's exploitative innovation strategy [52], Cui's market-driven business model innovation [53], Osiyevskyy and Dewald's 
exploitative-enhanced business model change [54], Luo and Xiang's perfecting business model innovation [50]. 9 items of "Frequently improve the existing major equipment maintenance services and their contents", "Continuously optimize the existing processes, knowledge and technologies related to equipment maintenance services and data analysis", "Accelerate the transaction speed of equipment maintenance services response to emergencies", "In short, equipment maintenance business model innovation is efficiency-oriented", and so on, are developed (see Table 5 for details).

The measurement items of novel equipment maintenance business model innovation mainly refer to Zott and Amit's novel business model [37], He and Wong's exploratory innovation strategy [52], Cui's driving-market business model innovation [53], Osiyevskyy and Dewald's exploratory-subverted business model change [54], Luo and Xiang 's pioneering business model innovation [50]. 9 items of "Explore new market opportunities and open up new markets across industries by using information technology", "Continuously look for new partners and discuss integrating them into processes of the existing equipment maintenance service", "Build a business ecosystem of real-time interaction and information sharing and strive to play a leading role", "In short, equipment maintenance business model innovation is novel-oriented", and so on, are developed (see Table 5 for details).

\subsection{Semi-Structured Interviews}

This paper conducted some semi-structured interviews to ensure that the proposed items can reflect truly and accurately the connotation of two types of equipment operation and maintenance business model innovation and to form a mature measurement scale with both practical and research value. The general managers and the members of strategic planning department of 10 manufacturing enterprises in China providing equipment maintenance services were interviewed from September to November 2017. Their business scopes involve manufacturing industries such as energy equipment, communication equipment, transportation equipment, instrumentation and so on. After semi-structured interviews, we have a deeper understanding about value creation mechanism of equipment maintenance services in manufacturing enterprises. The measurement items were adjusted and supplemented according to the interviews, the language modification in the statement of items was made.

The supplementary items are: two items of "Enable enterprises to make sensible equipment maintenance decisions under data-driven, improve the accuracy of equipment maintenance services transactions" and "Pay attention to the abnormal data analysis during equipment operating, try to reduce the failure rate of equipment" for efficient equipment maintenance business model innovation; two items of "Develop the new pricing model for equipment maintenance services" and "Pay attention to the habits data analysis of customers using equipment, try to find some new equipment maintenance services ideas" for novel equipment maintenance business model innovation (see Table 5 for details).

\subsection{Expert Reviews}

This paper conducted a content sufficiency test on the adjusted measurement scale to ensure the content validity of the measurement scale and more intuitively and clearly semantics [55]. Concretely, the adjusted measurement items were submitted to three experts respectively coming from strategic management, manufacturing servitization, and business model innovation. The face-to-face reviews were conducted. Experts pointed out that the measurement scale for business-oriented equipment maintenance business model innovation should be differentiated from the measurement scale for firm-level business model innovation. The items developed should conform to the actual situation of value creation of equipment maintenance services provided by manufacturing enterprises.

After that, the adjusted measurement items were revised, refined and deleted according to three experts' opinions. The deletion items are: "In short, equipment maintenance business model innovation is efficiency-oriented" for efficient equipment maintenance business model innovation; "In short, equipment maintenance business model innovation is novel-oriented" for novel equipment maintenance business model innovation (see Table 5 for details). 


\subsection{Small-Scale Questionnaire Pre-Test}

The scales after twice revisions were converted into the initial questionnaire with a five-point Likert scale for asking and scoring methods. Based on the EMBA relationships network of our school, the small-scale and small sample questionnaire pre-test was conducted. After collecting feedback from 30 manufacturing entrepreneurs, the language expression of the measurement items of equipment maintenance business model innovation was fine-tuned. Eventually, the initial measurement scale with 10 efficient and 10 novel equipment maintenance business model innovations were available for large-scale survey (see Table 5 for details).

\section{Validity Test of the Measurement Scale}

\subsection{Data Collection and Sample Features}

After ensuring the validity of the content, the validity and independence of the measurement scale are tested. Taking the manufacturing enterprises providing equipment maintenance services in China as our research objects, this paper collected data using the large-sample questionnaire through a combination of random and theoretical sampling methods. Manufacturing enterprises from the industries of energy equipment, transportation, instrument, etc. are experiencing the product commercialization traps, at the same time facing the market opportunities of customer enterprises for equipment maintenance outsourcing. They have begun to provide equipment maintenance services for customer enterprises to gain a sustainable competitive advantage. This is in line with the need for research on equipment maintenance business model innovation.

The large-scale questionnaire was issued and collected between December 2017 and April 2018. There are two ways to issue the questionnaires. First, the EMBA students of our school in the manufacturing field (mainly from Shaanxi, Jiangsu, Xinjiang, etc.) were entrusted to issue 120 questionnaires in the form of "snow-balling". After filtering, 99 valid questionnaires were obtained. Second, relying on the relationships network of our team, 300 questionnaires were issued to manufacturers in Shaanxi, Anhui, and Jiangsu by means of visiting, WeChat, and e-mail. After filtering, 244 valid questionnaires were obtained. A total of 420 questionnaires were issued and 343 valid questionnaires were obtained. Following the principle proposed by Andeson et al. (1988) that "Exploratory factor analysis and confirmatory factor analysis should use two independent sample data", the 343 questionnaires are randomly divided into two independent samples. One part ( $n=172$ ) was used for exploratory factor analysis, and the other part $(n=171)$ was used for confirmatory factor analysis, reliability and validity testing. This meets the test requirements recommended by Rummel (1970) that the sample sizes and the numbers of items are not less than 4:1. The sample features are shown in Table 6.

Table 6. The statistics of samples features.

\begin{tabular}{|c|c|c|c|c|c|c|c|}
\hline \multirow{2}{*}{\multicolumn{2}{|c|}{$\begin{array}{l}\text { Sample Feature Variables } \\
\qquad(n=172)\end{array}$}} & \multicolumn{2}{|c|}{ Exploratory Factor Analysis } & \multirow{2}{*}{\multicolumn{2}{|c|}{$\begin{array}{l}\text { Sample Feature Variables } \\
\qquad(n=171)\end{array}$}} & \multicolumn{2}{|c|}{ Confirmatory Factor Analysis } \\
\hline & & \multirow{2}{*}{$\begin{array}{c}\begin{array}{c}\text { Numbers of } \\
\text { Questionnaires }\end{array} \\
23\end{array}$} & \multirow{2}{*}{$\begin{array}{c}\text { Proportion } \\
13.4 \%\end{array}$} & & & \multirow{2}{*}{$\begin{array}{c}\begin{array}{c}\text { Numbers of } \\
\text { Questionnaires }\end{array} \\
24\end{array}$} & \multirow{2}{*}{$\begin{array}{c}\text { Proportion } \\
14.0 \%\end{array}$} \\
\hline & $<1$ & & & & $<1$ & & \\
\hline Capital scale & $1-5$ & 48 & $27.9 \%$ & Capital scale & $1-5$ & 60 & $35.1 \%$ \\
\hline (million) & $5-10$ & 42 & $24.4 \%$ & (million) & $5-10$ & 38 & $22.2 \%$ \\
\hline & $>10$ & 59 & $34.3 \%$ & & $>10$ & 49 & $28.7 \%$ \\
\hline Years of providing & $1-5$ & 33 & $19.1 \%$ & Years of providing & $1-5$ & 116 & $67.8 \%$ \\
\hline equipment & $6-10$ & 72 & $41.9 \%$ & equipment & $6-10$ & 33 & $19.3 \%$ \\
\hline maintenance & $11-20$ & 44 & $25.6 \%$ & maintenance & $11-20$ & 15 & $8.8 \%$ \\
\hline services & $>20$ & 23 & $13.4 \%$ & services & $>20$ & 7 & $4.1 \%$ \\
\hline \multirow{4}{*}{ Industry category } & $\begin{array}{l}\text { Energy equipment } \\
\text { manufacturing }\end{array}$ & 56 & $32.6 \%$ & \multirow{4}{*}{ Industry category } & $\begin{array}{l}\text { Energy equipment } \\
\text { manufacturing }\end{array}$ & 42 & $24.6 \%$ \\
\hline & $\begin{array}{l}\text { Transportation } \\
\text { manufacturing }\end{array}$ & 47 & $27.3 \%$ & & $\begin{array}{l}\text { Transportation } \\
\text { manufacturing }\end{array}$ & 52 & $30.4 \%$ \\
\hline & $\begin{array}{c}\text { Instrument } \\
\text { manufacturing }\end{array}$ & 32 & $18.6 \%$ & & $\begin{array}{c}\text { Instrument } \\
\text { manufacturing }\end{array}$ & 37 & $21.6 \%$ \\
\hline & $\begin{array}{c}\text { General } \\
\text { manufacturing }\end{array}$ & 37 & $21.5 \%$ & & $\begin{array}{c}\text { General } \\
\text { manufacturing }\end{array}$ & 40 & $23.4 \%$ \\
\hline
\end{tabular}




\subsection{Data Analysis}

\subsubsection{Measurement Scale Correction}

In this paper, exploratory factor analysis (EFA) on 20 items is conducted using the first part $(N=172)$ of the questionnaires adopting spss19.0. Prior to this, it is examined whether there is the possibility of sharing factors between items to ensure that the initial measurement scale suitable for factors extraction. The statistical results show that KMO is $0.942(>0.7)$, Bartlett's sphericity test chi-square is 2175.446 and the significant level (Sig. $=0.000$ ) is less than 0.001 . This shows that the initial scale compiled in this paper is suitable for factor analysis. We extract common factors using principal component analysis, filter factors with eigenvalue greater than 1 , perform maximum variance orthogonal rotation to the factor results, and finally extract two factors combining the scree plot. Two factors are corresponding to two types of equipment maintenance business model innovation, namely efficient type (factor 1, F1) and novel type (factor 2, F2). According to Zhang (2018), if the factor load of an item after orthogonal rotation on both factors is greater than 0.45 , this item should be deleted to improve the distinction of items. Thus, we delete "Improve the scalability of equipment maintenance business model".

Subsequently, the second EFA formed the result with the remaining 19 items (as shown in Table 7). The factor load corresponding to two factors is greater than 0.5 (as shown numbers in bold of Table 7), the eigenvalue of $\mathrm{F} 1$ is 6.753 , the eigenvalue of $\mathrm{F} 2$ is 7.491 , and the cumulative variance contribution rate is $74.967 \%(>50 \%)$. The F1 scale includes a total of nine measurement items with a Cronbach's $\alpha$ value of 0.955 . The F2 scale includes a total of 10 measurement items with a Cronbach's $\alpha$ value of 0.964. It shows that the scale has stability and reliability, as shown in Table 7.

Table 7. The results of exploratory factor analysis on the measurement scale.

\begin{tabular}{|c|c|c|}
\hline Measurement Items & F1 & F2 \\
\hline \multicolumn{3}{|l|}{ F1: Efficient equipment maintenance business model innovation } \\
\hline Eff1 Frequently improve the existing major equipment maintenance services and their contents. & 0.821 & 0.253 \\
\hline $\begin{array}{l}\text { Eff } 2 \text { Continuously optimize the existing processes, knowledge and technologies related to } \\
\text { equipment maintenance services and data analysis. }\end{array}$ & 0.846 & 0.306 \\
\hline Eff3 Pursue to simple transaction activities of equipment maintenance services. & 0.782 & 0.268 \\
\hline $\begin{array}{l}\text { Eff } 4 \text { Accelerate the transaction speed of equipment maintenance services response to } \\
\text { emergencies. }\end{array}$ & 0.837 & 0.150 \\
\hline $\begin{array}{l}\text { Eff5 Strive to consolidate and expand the existing equipment maintenance market, improve } \\
\text { transaction channels in the industry of equipment maintenance services. }\end{array}$ & 0.808 & 0.223 \\
\hline $\begin{array}{l}\text { Eff6 Information on the requirements, usage and delivery of maintenance services involved in } \\
\text { equipment maintenance service transactions is transparent and visual. }\end{array}$ & 0.789 & 0.321 \\
\hline Eff7 Actively explore to save the costs associated with equipment maintenance services. & 0.826 & 0.266 \\
\hline $\begin{array}{l}\text { Eff8 Enable enterprises to make sensible equipment maintenance decisions under data-driven, } \\
\text { improve the accuracy of equipment maintenance services transactions. }\end{array}$ & 0.838 & 0.224 \\
\hline $\begin{array}{l}\text { Eff9 Pay attention to the abnormal data analysis during equipment operating, try to reduce the } \\
\text { failure rate of equipment. }\end{array}$ & 0.845 & 0.257 \\
\hline \multicolumn{3}{|l|}{ F2: Novel equipment maintenance business model innovation } \\
\hline $\begin{array}{l}\text { Nov1 Committed to provide innovative and distinctive equipment maintenance service content } \\
\text { and combinations for customers. }\end{array}$ & 0.306 & 0.846 \\
\hline $\begin{array}{l}\text { Nov2 Continuously explore the new processes, knowledge and technologies related to } \\
\text { equipment maintenance services and data analysis. }\end{array}$ & 0.278 & 0.847 \\
\hline $\begin{array}{l}\text { Nov3 Explore new market opportunities and open new markets across industries by using } \\
\text { information technology. }\end{array}$ & 0.283 & 0.815 \\
\hline $\begin{array}{l}\text { Nov4 Continuously look for new partners and discuss integrating them into processes of the } \\
\text { existing equipment maintenance service. }\end{array}$ & 0.235 & 0.810 \\
\hline
\end{tabular}


Table 7. Cont.

\begin{tabular}{lcc}
\hline \multicolumn{1}{c}{ Measurement Items } & F1 & F2 \\
\hline $\begin{array}{l}\text { Nov5 Build a business ecosystem of real-time interaction and information sharing and strive to } \\
\text { play a leading role. }\end{array}$ & 0.186 & $\mathbf{0 . 8 3 8}$ \\
\hline $\begin{array}{l}\text { Nov6 Establish the new transaction mechanism for maintenance services, and strive to establish } \\
\text { new behavior routine and norms. }\end{array}$ & 0.237 & $\mathbf{0 . 8 4 0}$ \\
\hline $\begin{array}{l}\text { Nov7 Bring unique experience value to customers and improve customer loyalty by the } \\
\text { innovative equipment maintenance services. }\end{array}$ & 0.353 & $\mathbf{0 . 7 7 7}$ \\
\hline Nov8 Share benefits and risks of equipment maintenance services with partners, customers. & 0.237 & $\mathbf{0 . 8 3 4}$ \\
\hline Nov9 Develop the new pricing model for equipment maintenance services. & 0.212 & $\mathbf{0 . 8 5 1}$ \\
\hline $\begin{array}{l}\text { Nov10 Pay attention to the habits data analysis of customers using equipment, try to find some } \\
\text { new equipment maintenance services ideas. }\end{array}$ & 0.229 & $\mathbf{0 . 8 4 4}$ \\
\hline \multicolumn{1}{c}{ Cronbach's $\alpha$} & 0.955 & 0.964 \\
\hline Eigenvalue & 6.753 & 7.491 \\
\hline
\end{tabular}

\subsubsection{Measurement Scale Test}

In this paper, confirmatory factor analysis (CFA) on the 19 items is conducted using the second part $(N=171)$ of the questionnaires adopting AMOS 17.0 to ensure the stability of the factors structure obtained by EFA. Specifically, the two factors of efficient equipment maintenance business model innovation (F1) and novel equipment maintenance business model innovation (F2) are regarded as the latent variables. Their respective items are treated as the explicit variables. Through the SEM analysis program, we explore whether the factors structures (latent variables) of the scale match the actual searched data, and whether the items (explicit variables) of the scale can be effectively used as the measurement variables of two factors. The path diagram of CFA is shown in Figure 1, and the analysis results are shown in Table 8.

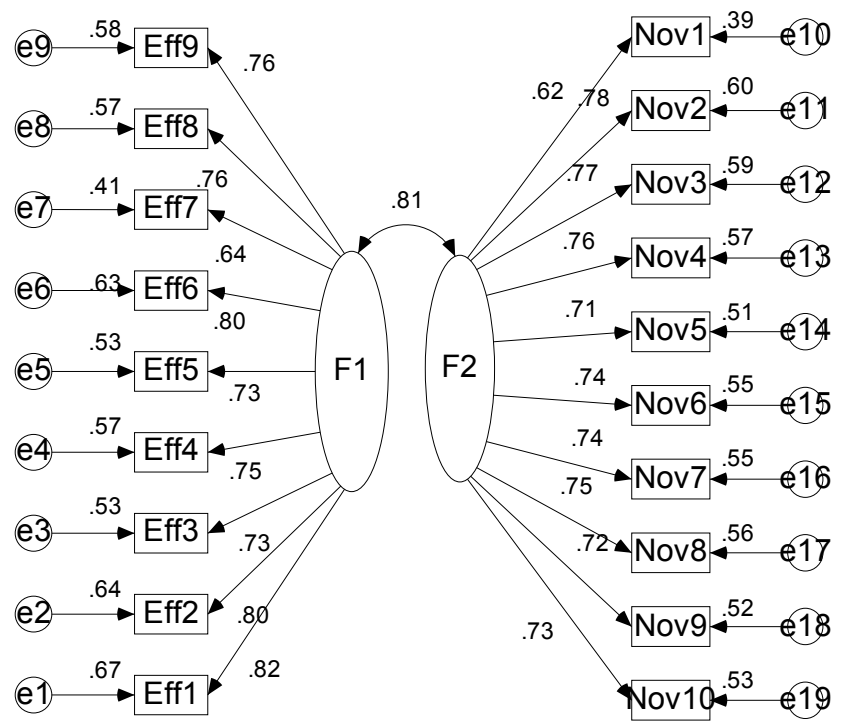

Figure 1. The path diagram of CFA of measurement model.

Table 8. Confirmatory factor fitting result of measurement scale.

\begin{tabular}{ccccccccccc}
\hline Model & $\chi^{2}$ & $\chi^{2} / \mathbf{d f}$ & RMSEA & RMR & GFI & IFI & NFI & CFI & PNFI & PGFI \\
\hline Standards & Smaller, better & $<2$ & $<0.08$ & $<0.05$ & $>0.9$ & $>0.9$ & $>0.9$ & $>0.9$ & $>0.5$ & $>0.5$ \\
\hline Single factor & 392.019 & 2.579 & 0.096 & 0.058 & 0.796 & 0.879 & 0.816 & 0.877 & 0.725 & 0.611 \\
\hline Two-factor & 230.336 & 1.525 & 0.056 & 0.036 & 0.884 & 0.960 & 0.892 & 0.959 & 0.788 & 0.702 \\
\hline
\end{tabular}


It can be found from Table 8, compared with the single factor model, the absolute fitting index, relative fitting index and simple fitting index of the two-factor model meet the acceptable standards. It is confirmed that the relationships between the two factors and the 19 items proposed in this paper are stable. The measurement model with higher degree of fitting is more suitable as the measurement system for equipment maintenance business model innovation in the digitalization context.

After the model is fitted, the reliability and validity of the scale are further examined. The reliability test is performed by using the 171 samples of the second part. We find that the Cronbach's $\alpha$ of efficient and novel equipment maintenance business model innovation is 0.922 and 0.920 , respectively $(>0.7)$. This indicates that the scale has good reliability and reliable internal consistency as the measurement tool for equipment maintenance business model innovation. It can be found from the path diagram of CFA that the path coefficients of the 19 items (explicit variables) corresponding to the two factors (latent variable) are all greater than 0.5 (factor load). AVE of F1 and F2 is calculated to be 0.572 and 0.597 respectively $(>0.5)$. This indicates that both factors have good convergent validity. At the same time, the correlation between the two factors is $0.749^{* *}$, which is less than the square root of AVE (see Table 9 for details). This shows that the two factors of efficient and novel have better discriminant validity. In summary, it can be determined that the questionnaire developed in this paper has better structural validity.

Table 9. The correlation coefficient and descriptive statistics of variables.

\begin{tabular}{|c|c|c|c|c|}
\hline Factor & Average Value & Standard Deviation & F1 & F2 \\
\hline Efficient equipment maintenance business model innovation (F1) & 3.42 & 0.63 & 0.756 & $0.749^{* *}$ \\
\hline Novel equipment maintenance business model innovation (F2) & 3.96 & 0.78 & $0.749^{* *}$ & 0.773 \\
\hline
\end{tabular}

Note: ** indicates significant correlation on $p<0.01$ (both sides), the value of the italic on the diagonal is the square root of the corresponding AVE.

\section{Conclusions and Future Research}

\subsection{Conclusions and Implications}

In the digitalization context, a large numbers of traditional manufacturing enterprises have begun to use digitalization technologies to provide equipment maintenance services to customer enterprises as an important way to gain sustainable competitive advantage. This paper explored the connotations and types of equipment maintenance business model innovation at the business-level. Then, we developed and tested the measurement scale of equipment maintenance business model innovation. The theoretical contributions of this paper are mainly reflected in the following three aspects:

Firstly, this paper analyzed and defined the connotation of equipment maintenance business model innovation in the digitalization context. The theoretical research on business model innovation in academia was almost at the firm level. It is difficult to provide theoretical guidance for manufacturing enterprises on how to capture economic benefit and gain sustainable competitive advantage through equipment maintenance services provision under the two-wheel drive of digitalization technologies innovation and customer outsourcing equipment maintenance demands. This paper analyzed and refined the connotation of equipment maintenance business model innovation in the digitalization context through literature investigation. Equipment maintenance business model innovation refers to manufacturing enterprises redesign and optimize equipment performance or maintenance services' contents, change the process of value creation of equipment maintenance services, propose the new equipment maintenance services transaction and profit distribution methods with customer enterprises by using the functions of monitoring, diagnosis, prediction, and optimization of digitalization equipment maintenance services. It is a systemic innovation based on comprehensive consideration of customers' needs, equipment maintenance resources owned or integrated, and equipment maintenance stakeholder relationships.

Secondly, this paper classified equipment maintenance business model innovation in the digitalization context into efficient and novel. The existing conclusions on the classification of business 
model innovation types were not uniform. Based on the mainstream classification criteria of business model innovation, following the common classification criterion of Schumpeter's (1934) source of value under the uncertainty environment- "innovation and efficiency", this paper divided equipment maintenance business model innovation into efficient and novel. The concepts of two-equipment maintenance business model innovation are described by combining digitalization equipment maintenance services and business model gestalt theory. In the digitalization context, manufacturing enterprises adopt (1) efficient equipment maintenance business model innovation, using digitalization technologies to monitor equipment operating condition, analyze equipment operating abnormal data, predict equipment life cycle, and achieve efficient equipment maintenance services transactions, thereby consolidate and expand the existing equipment maintenance market, optimize equipment design and functions, help customer enterprises avoid downtime and control equipment maintenance service costs in real-time; and (2) novel equipment maintenance business model innovation, using digitalization technologies to monitor equipment operating environment, analyze the customers' habits and preferences of using equipment, predict the customers' implicit needs, and provide new and unique solutions and services combination to customers through searching for new equipment maintenance services opportunities and services ideas. Thereby new equipment maintenance services market is opened and a cross-industry business ecosystem is built. These will help customer enterprises improve equipment value in-use and optimize operation processes. In turn, manufacturing enterprises will gain benefit and sustainable competitive advantage from these emerging equipment maintenance service flows.

Finally, this paper designed and validated 19 measurement items for equipment maintenance business model innovation in the digitalization context. To ensure the reliability and validity of the scale, based on the literature investigation, this paper conducted a semi-structured interview with the general managers and strategic planning department members of 10 manufacturing companies that have provided maintenance services in China. The interviews found that the industry is more concerned about new technologies especially in the digitalization context, the changes brought by the digitalization resources to value creation of equipment maintenance services. Therefore, combining with interviews, four items of "Enable enterprises to make sensible equipment maintenance decisions under data-driven, improve the accuracy of equipment maintenance services transactions", "Pay attention to the abnormal data analysis during equipment operating, try to reduce the failure rate of equipment", "Develop the new pricing model for equipment maintenance services", and "Pay attention to the habits data analysis of customers using equipment, try to find some new equipment maintenance services ideas" were increased. After that, the item "Improve the scalability of equipment maintenance business model" was removed by exploratory factor analysis due to the load greater than 0.45 on both factors. Finally, this paper formed two types (two factors), a measurement scale consisting of 19 items. All the items were guaranteed to be combined with the actual situation of the business-level value creation of equipment maintenance services, different from business model innovation at the firm-level.

\subsection{Comparison with Previous Studies}

The providing of maintenance services has become an important way for manufacturing enterprises to gain sustainable competitive advantage. Business model is a carrier of value creation and realization of maintenance services, how to innovate or design equipment maintenance services business-level business model has become a key to sustainable competition of today's manufacturing enterprises [6]. However, there were few works on the concept of equipment maintenance business model innovation [16], and the choice of innovative behavior in academia, which limited the research and development of variables related to equipment maintenance services.

In this paper, we have made some interesting and new findings that are different from earlier studies. First of all, we broke through the limitations of existing research on business model innovation on firm-level $[7,33,40-44]$, explored the connotation and types of equipment maintenance business 
model innovation on business-level following business model gestalt theory, combining with the functions of digitalization equipment maintenance services. Our research not only refined business model innovation theory from the firm-level to the business-level, but also could provide theoretical guidance for manufacturing enterprises to improve equipment maintenance services innovation and service performance from the source of value, thus, to form differentiated sustainable competitive advantages. In addition, we overcame the deficiency of the existing research on equipment maintenance business model innovation only staying at the point of expounding its importance [30,45], developed and tested the measurement scale of equipment maintenance business model innovation according to the scale development programs. It could provide a measurement tool for quantitative research on equipment maintenance business model innovation.

\subsection{Future Directions}

We now discuss the limitations of this paper and the direction to be extended in future research. First, the large sample data in this paper are all cross-sectional data, unable to explore the dynamic evolution of equipment maintenance business model innovation. In the future, we should further collect vertical data about equipment maintenance business model innovation, ensure the comprehensiveness and integrity of research on equipment maintenance business model innovation. Second, in the digitalization context, the efficient and novel of the two types of equipment maintenance business model innovation are not opposite. In the future, it is necessary to analyze the balance between the two. Third, it is a research question worthy of further discussion that the relationships between equipment maintenance business model innovation and business strategy, business performance, and other variables in the digitalization context.

Author Contributions: All authors contributed extensively to the work presented in this article. Designing and writing: R.Z.; revising and review: J.C.; collection of data: D.W. All authors read and approved the final manuscript.

Funding: This research was funded by National Natural Science Foundation of China [Grant No. 71272117], National Social Science Foundation of China [Grant No. 16CGL008], Key Discipline Construction Project in Shaanxi Provincial of China [Grant No. 107-00x902].

Acknowledgments: This work was supported by National Natural Science Foundation of China [Grant No. 71272117], National Social Science Foundation of China [Grant No. 16CGL008], Key Discipline Construction Project in Shaanxi Provincial of China [Grant No. 107-00x902].

Conflicts of Interest: The authors declare no conflict of interest.

\section{References}

1. Jian, Z.-Q.; Liu, X.-Y.; Li, L. Organization Design for Manufacturing Servitization: A Literature Review and Prospects. Bus. Manag. J. 2017, 39, 194-208.

2. Alaswad, S.; Xiang, Y. A review on condition-based maintenance optimization models for stochastically deteriorating system. Reliabil. Eng. Syst. Saf. 2017, 157, 54-63. [CrossRef]

3. IoT Analytics. Predictive Maintenance. Available online: https://iot-analytics.com/product/predictivemaintenance-market-report-2017-2022/ (accessed on 22 March 2017).

4. Peng, Y.; Dong, M.; Zuo, M.J. Current Condition of Machine Prognostics in Condition-Based Maintenance: A Review. Int. J. Adv. Manuf. Technol. 2010, 50, 297-313. [CrossRef]

5. Komijani, H.; Shahin, M.; Jabbarzadeh, A. Condition-based maintenance considering shock and degradation processes. Decis. Sci. Lett. 2017, 6, 151-164. [CrossRef]

6. Berger, R. Predictive maintenance: Potential explosion points in the field of industrial digitalization. China Ind. Rev. 2017, 11, 72-78.

7. Chesbrough, H.; Rosenbloom, R.S. The role of the business model in capturing value from innovation: Evidence from Xerox Corporation's technology spin-off companies. Ind. Corp. Chang. 2002, 11, 529-555. [CrossRef]

8. Xia, Q.-H.; Lou, H.-Y. Business model rigidity: Structural composition and evolutionary mechanism. China Ind. Econ. 2014, 11, 148-160. 
9. Geissdoerfer, M.; Vladimirova, D.; Evans, S. Sustainable business model innovation: A review. J. Clean. Prod. 2018, 198, 401-416. [CrossRef]

10. Mitchell, D.; Coles, C. The ultimate competitive advantage of continuing business model innovation. J. Bus. Strategy 2003, 24, 15-21. [CrossRef]

11. Rashid, A.; Asif, F.M.; Krajnik, P.; Nicolescu, C.M. Resource Conservative Manufacturing-An essential change in business and technology paradigm for sustainable manufacturing. J. Clean. Prod. 2013, 57, 166-177. [CrossRef]

12. Tukker, A. Eight types of product-service system: Eight ways to sustainability? Experiences from SusProNet. Bus. Strategy Environ. 2004, 13, 246-260. [CrossRef]

13. Porter, M.E.; Heppelmann, J.E. How Smart, Connected Products Are Transforming Competition. Harv. Bus. Rev. 2014, 12, 64-88.

14. Song, T.-X.; Zhang, T.; Zhang, Y.-M.; Huang, B.-Q. Technology of operation and maintenance management for offshore wind farm based on lean MRO thinking. Comput. Integr. Manuf. Syst 2017, 23, 387-395.

15. Hu, B.-L. The Dimensions of the Business Model of the Internet of Things and Their Influence on Firm Performance. Sci. Technol. Prog. Policy 2015, 11, 16-22.

16. Hyvönen, H. Operations \& Maintenance Business Model Transformation-Multiple Case Studies. Mod. Econ. 2014, 5, 1161-1170.

17. Ahuja, S.; Khamba, J.S. Assessment of contributions of successful TPM initiatives towards competitive manufacturing. J. Qual. Maint. Eng. 2008, 14, 356-374. [CrossRef]

18. Parida, A.; Kumar, U. Maintenance performance measurement (MPM): Issues and challenges. J. Qual. Maint. Eng. 2006, 12, 459-478. [CrossRef]

19. Nielsen, J.S.; Sørensen, J.D. Maintenance Optimization for Offshore Wind Turbines using POMDP; American University of Armenia Press: Yrevan, Armenia, 2012.

20. Jefferis, T.; Wong, E.L.; Montgomery, N. Proportional hazards modeling of engine failures in military vehicles. J. Qual. Maint. Eng. 2010, 16, 144-155.

21. Gupta, D.; Günalay, Y.; Srinivasan, M.M. The relationship between preventive maintenance and manufacturing system performance. Eur. J. Oper. Res. 2001, 132, 146-162. [CrossRef]

22. Dekker, R.; Scarf, P.A. On the impact of optimisation models in maintenance decision making: The state of the art. Reliabil. Eng. Syst. Saf. 1998, 60, 111-119. [CrossRef]

23. US Department of Defense. Condition-Based Maintenance Assessment Report; US Department of Defense: Washington, DC, USA, 2000.

24. Prajapati, A.; Bechtel, J.; Ganesan, S. Condition based maintenance: A survey. J. Qual. Maint. Eng. 2012, 18, 384-400. [CrossRef]

25. Basri, E.I.; Abdul Razak, I.H.; Ab-Samat, H.; Kamaruddin, S. Preventive Maintenance (PM) planning: A review. J. Qual. Maint. Eng. 2017, 23, 114-143. [CrossRef]

26. Florian, M.; Sørensen, J.D. Wind Turbine Blade Life-Time Assessment Model for Preventive Planning of Operation and Maintenance. J. Mar. Sci. Eng. 2015, 3, 1027-1040. [CrossRef]

27. Hognelid, P.; Kalling, T. Internet of Things and Business Models. In Proceedings of the International Conference on Standardization and Innovation in Information Technology, Bandung, Indonesia, 24-27 October 2016.

28. Xie, J.-P.; Liang, L.; Gong, H.-T. Business Model Innovation Based on Customer Value Under the IoT Circumstances. Econ. Manag. J. 2015, 188-199.

29. Kujala, S.; Artto, K.; Aaltonen, P.; Turkulainen, V. Business models in project-based firms-Towards a typology of solution-specific business models. Int. J. Proj. Manag. 2010, 28, 96-106. [CrossRef]

30. Gomez Fernandez, J.F.; Fumagalli, L.; Macchi, M.; Crespo Marquez, A. A score card approach to investigate the IT in the Maintenance Business Models. In Proceedings of the Annual 10th International Conference on the Modern Information Technology in the Innovation Processes of the Industrial Enterprises, Prague, Czech Republic, 12-14 November 2008; pp. 12-14.

31. Amit, R.; Zott, C. Value creation in E-business. Strateg. Manag. J. 2001, 22, 493-520. [CrossRef]

32. Osterwalder, A.; Pigneur, Y. Business Model Generation-A Handbook for Visionaires, Game Changers, and Challengers; New York Wiley: New York, NY, USA, 2010.

33. Teece, D.J. Business models, business strategy and innovation. Long Range Plan. 2010, 43, 172-194. [CrossRef] 
34. Samavi, R.; Yu, E.; Topaloglou, T. Strategic reasoning about business models: A conceptual modeling approach. Inf. Syst. e-Bus. Manag. 2009, 7, 171-198. [CrossRef]

35. Bucherer, E.; Eisert, U.; Gassmann, O. Towards Systematic Business Model Innovation: Lessons from Product Innovation Management. Creat. Innov. Manag. 2012, 21, 183-198. [CrossRef]

36. Chesbrough, H. Business Model Innovation: Opportunities and Barriers. Long Range Plan. 2010, 43, $354-363$. [CrossRef]

37. Zott, C.; Amit, R. Business Model Design and the Performance of Entrepreneurial Firms. Organ. Sci. 2007, 18, 181-199. [CrossRef]

38. Zott, C.; Amit, R. Business Model Innovation. Res.-Technol. Manag. 2015, 57, 500-504.

39. Zott, C.; Amit, R.; Massa, L. The Business Model: Recent Developments and Future Research. Soc. Sci. Electron. Publ. 2011, 37, 1019-1042.

40. Nyangon, J.; Byrne, J. Diversifying Electricity Customer Choice: REVing Up the New York Energy Vision for Polycentric Innovation. Energy Syst. Environ. 2018, 3-24. [CrossRef]

41. Sosna, M.; Trevinyo-Rodríguez, R.N.; Velamuri, S.R. Business Model Innovation through Trial-and-Error Learning: The Naturhouse Case. Long Range Plan. 2010, 43, 383-407. [CrossRef]

42. Foss, N.J.; Saebi, T. Fifteen Years of Research on Business Model Innovation: How Far Have We Come, and Where Should We Go? J. Manag. 2017, 43, 200-227. [CrossRef]

43. Wang, X.-D.; Dong, D.-H. A Review of the Literature of the Concept of Business Model Innovation and Prospects. For. Econ. Manag. 2013, 35, 29-36.

44. Luo, X.-W.; Xiang, G.-P.; Ning, P.; Cheng, C. The impact of BMI on new venture performance: The effects of legitimacy and policy orientation. Stud. Sci. Sci. 2017, 35, 1073-1084.

45. Fumagalli, L.; Garetti, M.; Macchi, M. Investigating business models when adopting new ICT systems for condition-based maintenance: A case study analysis. In Proceedings of the Fifteenth International Working Seminar on Production Economics, Innsbruck, Austria, 19-23 February 2008; pp. 209-219.

46. Liu, G.; Wang, D.; Li, J. Top Management Team Heterogeneity, Business Model Innovation and Enterprise Performance. Res. Econ. Manag. 2017, 3, 105-114.

47. Li, H.-L. Research on Business Model Classification Based on the Perspective of Value Creation-Taking the Classification Application of Three Typical Enterprises as an Example. Manag. Rev. 2018, 257-272.

48. Clauss, T. Measuring business model innovation: Conceptualization, scale development, and proof of performance. $R$ D Manag. 2017, 47, 385-403. [CrossRef]

49. Churchill, G.A. A Paradigm for Developing Better Measures of Marketing Constructs. J. Mark. Res. 1979, 16, 64-73. [CrossRef]

50. Luo, X.-W.; Liu, Y.; Xiang, G.-P.; Ning, P. Business Model Innovation in the Context of China's Transitional Economy: Theme Design and Scale Development. For. Econ. Manag. 2018, 40, 33-49.

51. Zhang, X.-E.; Zhao, M.-H. The connotation, dimensions and measurement of entrepreneurial success. Stud. Sci. Sci. 2018, 36, 474-483.

52. He, Z.L.; Wong, P.K. Exploration vs. Exploitation: An Empirical Test of the Ambidexterity Hypothesis. Organ. Sci. 2004, 15, 481-494. [CrossRef]

53. Cui, N.; Jiang, Y.-R. Influence of the Matching between Business Model Design and Strategic Orientation on Business Performance. J. Bus. Econ. 2013, 45-53.

54. Osiyevskyy, O.; Dewald, J. Explorative Versus Exploitative Business Model Change: The Cognitive Antecedents of Firm-Level Responses to Disruptive Innovation. Strateg. Entrep. J. 2015, 9, 58-78. [CrossRef]

55. Luo, S.-Q. Management Survey Methodology; Chongqing University Press: Chongqing, China, 2014.

(C) 2018 by the authors. Licensee MDPI, Basel, Switzerland. This article is an open access article distributed under the terms and conditions of the Creative Commons Attribution (CC BY) license (http://creativecommons.org/licenses/by/4.0/). 